\title{
Characterization and molecular epidemiology of Staphylococcus aureus strains resistant to beta-lactams isolated from the milk of cows diagnosed with subclinical mastitis
}

\author{
Geziella Áurea Aparecida Damasceno Souza ${ }^{1}$, Anna Christina de Almeida ${ }^{1}$, Mauro Aparecido de Sousa Xavier ${ }^{2}$, \\ Lívia Mara Vitorino da Silva ${ }^{1}$, Cintya Neves Sousa ${ }^{1}$, Demerson Arruda Sanglard ${ }^{3}$ and Alessandra Rejane Ericsson de \\ Oliveira Xavier ${ }^{1}$
}

\begin{abstract}
1. Federal University of Minas Gerais, Institute of Agrarian Sciences, Center for Research in Agrarian Sciences, Laboratory of Animal Health, Montes Claros, Minas Gerais, Brazil; 2. State University of Montes Claros, Center of Biological and Health Sciences, Microbiology Laboratory, Montes Claros, Minas Gerais, Brazil; 3. Federal University of Minas Gerais, Institute of Agrarian Sciences, Center for Research in Agrarian Sciences, Laboratory of Biotechnology, Montes Claros, Minas Gerais, Brazil.

Corresponding author: Alessandra Rejane Ericsson de Oliveira Xavier, e-mail: ericsson_aerc@yahoo.com.br Co-authors: GAADS: geziella.ufmg@gmail.com, ACA: aca2006@ica.ufmg.br, MASX: mauro.xavier@unimontes.br, LMVD: Iviavitorino@yahoo.com.br, CNS: cintyamicro@hotmail.com, DAS: demerson.ufmg@gmail.com Received: 12-09-2019, Accepted: 07-11-2019, Published online: 11-12-2019
\end{abstract}

doi: www.doi.org/ 10.14202/vetworld.2019.1931-1939 How to cite this article: Souza GAAD, Almeida AC, Xavier MAS, Silva LMV, Sousa CN, Sanglard DA, Xavier AREO (2019) Characterization and molecular epidemiology of Staphylococcus aureus strains resistant to beta-lactams isolated from the milk of cows diagnosed with subclinical mastitis, Veterinary World, 12(12): 1931-1939.

\begin{abstract}
Background and Aim: The term ESKAPE, recognized by the WHO, is an acronym, which refers to the pathogens Enterococcus faecium, Staphylococcus aureus, Klebsiella pneumoniae, Acinetobacter baumannii, Pseudomonas aeruginosa, and Enterobacter spp., which is extremely virulent and multidrug-resistant. Although the term is used to designate nosocomial pathogens, in a milking environment, strains of Methicillin-resistant $S$. aureus have been isolated from cattle diagnosed with clinical and subclinical mastitis. Resistant strains may be involved in the transfer of genes conferring resistance to beta-lactam antimicrobials among the species of microorganisms related to mastitis etiology. This study aimed to trace the phenotypic and genotypic profiles of susceptibility to beta-lactams in $S$. aureus isolated from milk of cattle diagnosed with subclinical mastitis obtained from different rural properties located in the North of Minas Gerais State, Brazil.
\end{abstract}

Materials and Methods: Sixteen microorganisms previously identified as $S$. aureus isolated from milk of cattle diagnosed with subclinical mastitis were submitted to matrix-assisted laser desorption/ionization-time-of-flight (MALDI-TOF), mass spectrometry, and polymerase chain reaction (PCR) analysis for microbial species confirmation. The S. aureus beta-lactams antimicrobial phenotypic resistance profile was investigated by disk diffusion method. PCR methods were also performed to investigate the $S$. aureus genotypic beta-lactams resistance profile. For this purpose, $b l a_{\mathrm{Z}}, m e c \mathrm{~A}, m e c_{\mathrm{ALGA} 251}, b l a_{\mathrm{Oxa} 23}$, and $b_{l a}$ Kenes were screened among $S$. aureus isolates. The genetic diversity of $S$. aureus by fingerprint random amplified polymorphic DNA (RAPD)-PCR was also performed in this study.

Results: All isolates showed phenotypic resistance to at least three beta-lactams, among which was meropenem. None of the isolates tested positive for the genes $m e c_{\mathrm{ALGA} 251}, b l a_{\mathrm{Oxa23}}$, and $b l a_{\mathrm{KPC}}$; however, the presence of the genes $b l a_{\mathrm{Z}}$ and mecA was detected among the isolates. The fingerprint analysis divided isolates into two distinct groups and 15 different subgroups. Despite the presence of clonality among the isolates, the PCR-RAPD analysis unveiled a heterogeneous profile with genetic diversity among the $S$. aureus isolates.

Conclusion: In this study, we identified beta-lactams resistant $S$. aureus strains isolated from the milk of cows diagnosed with subclinical mastitis. The $S$. aureus beta-lactams resistance was investigated using a phenotypic and genotypic approach. We believe that molecular epidemiology, improved knowledge, and genetic basis of resistance to beta-lactams might assist in asserting guidelines for better management practices of dealing with subclinical mastitis and mapping of origin of resistant pathogens in the studied Brazilian area.

Keywords: beta-lactams, genetic diversity, infection, resistance genes, Staphylococcus aureus.

\section{Introduction}

Staphylococcus aureus is universally recognized as the causative agent of mammary glands infections in

Copyright: Souza, et al. Open Access. This article is distributed under the terms of the Creative Commons Attribution 4.0 International License (http://creativecommons.org/licenses/by/4.0/), which permits unrestricted use, distribution, and reproduction in any medium, provided you give appropriate credit to the original author(s) and the source, provide a link to the Creative Commons license, and indicate if changes were made. The Creative Commons Public Domain Dedication waiver (http://creativecommons.org/ publicdomain/zero/1.0/) applies to the data made available in this article, unless otherwise stated. bovine herds [1-5]. Subclinical mastitis (SM) is the most prevalent infectious breast disease in dairy cows [6]. Although SM is characterized by the absence of clinical signs and several detrimental effects on milk production is noticed, its milk is marketed $[2,6]$. Programs for mastitis prevention and treatment include the use of antimicrobials, among which are the beta-lactams $[5,7]$. However, the indiscriminate use of antibiotics, which can lead to multidrug resistance, and increased risk of the presence of antimicrobial residues in milk, has made mastitis a disease of significant importance to 
public health [8,9]. S. aureus harbors genes that impart resistance to antimicrobial agents, which leads to complications in the treatment of their infections as well as increases the cost of treatments [3,7].

The resistance of Staphylococcus spp. to beta-lactams, specifically to methicillin in $S$. aureus, is quite advanced, and it is a widespread public health problem worldwide [10-13]. Two mechanisms have been described for the resistance to beta-lactams in the genus Staphylococcus. One of them is the production of the beta-lactamase enzyme encoded by the gene blaZ [11,14-17]. Another mechanism involves the synthesis of penicillin-binding protein 2A (PBP2A) with a low affinity for binding to penicillin coded by the gene mecA and its counterparts, among which mec $_{A \mathrm{LGA} 251}[10-12,16,18]$. The presence of genes that encode the expression of carbapenem-type beta-lactamases has been described in Acinetobacter spp. [19,20] and Klebsiella pneumoniae [21,22]. These organisms are also potential etiologic agents of bovine mastitis [2326], as well as disseminators of resistance genes to other pathogens [27]. In Acinetobacter baumannii, resistance to carbapenem agents can be attributed to the presence of the gene $b l a_{\mathrm{Oxa23}}[19,20]$ and to the gene $b l a_{\mathrm{KPC}}$ in $K$. pneumoniae $[21,22]$. The presence of the gene bla $_{\mathrm{Oxa23}}$ has already been reported in pathogens other than A. baumannii, confirming the transferability of this gene to other species of microorganisms [28,29]. Strains of Escherichia coli, Enterobacter spp., Salmonella spp., Acinetobacter spp., and Pseudomonas spp. carrying plasmids containing the gene $b l a_{\mathrm{KPC}}$ have also been reported in countries such as the United States, Israel, China, Brazil, and the European continent [30-32].

Molecular epidemiological studies have contributed to the mapping of sources, routes of transmission, and prognosis for many pathogens that cause bovine mastitis, as well as to the understanding of the adaptation mechanisms of the host and the causes of the disease [7,33,34]. Quick and simple techniques based on identifying fingerprints of repetitive elements have been described for studies of genetic diversity and epidemiological analysis of the genus Staphylococcus [7,34-38]. Considering this background, this study aimed to trace the phenotypic and genotypic profiles of susceptibility to beta-lactams in $S$. aureus isolated from bovine milk of herd with subclinical mastitis from different rural properties located in the North of Minas Gerais, Brazil. The analysis of the genetic diversity of isolates of $S$. aureus by fingerprint random amplified polymorphic DNA (RAPD) - polymerase chain reaction (PCR) was also included in this study.

\section{Materials and Methods}

\section{Ethical approval}

This work was performed within the ethical standards approved by the Ethics and Animal Experimentation of Federal University of Minas Gerais (UFMG) under protocols number 145/2013 and 90/2018.
Bacterial isolates and profile of sensitivity to beta-lactam antimicrobials

Sixteen samples of $S$. aureus maintained in the cell bank of the Animal Health laboratory of the Institute of Agrarian Sciences at the Federal University of Minas Gerais were selected. The samples of $S$. aureus were isolated from the milk of cows diagnosed with subclinical mastitis originating from seven rural properties in the North of Minas Gerais, Brazil: Janaúba (FL[15 48'13"S], and NP[43¹9'3"W]), Porteirinha (MU[1544'38',S]), Icaraí de Minas (VA[16 11'46'S]), Matias Cardoso(FH[1451'20's]), São João da Lagoa (SL[1646'42"S]), and Bocaiuva (TR[17\%6'55'S]). The identification of isolates at the species level was performed by detection of the gene femA, a species-specific marker for $S$. aureus as described by Xavier et al. [7].

The susceptibility to beta-lactam antibiotics was determined by the disk diffusion method according to the Clinical and Laboratory Standards Institute guideline [39] using the following antimicrobials (Laborclin): Amoxicillin - $10 \mu \mathrm{g}$ (AMO), cefoxitin - $30 \mu \mathrm{g}$ (CFO), oxacillin - $1 \mu \mathrm{g}$ (OXA), ampicillin - $10 \mu \mathrm{g}$ (AMP), and meropenem - $10 \mu \mathrm{g}$ (MER). A standard strain of S. aureus ATCC 25923 was used as positive control.

\section{Confirmation of the identification of $S$. aureus to spe- cies level by MALDI-TOF MS}

The cryopreserved isolates genotyped as S. aureus were reactivated by sowing in Brain Heart Infusion (BHI) agar medium (BHI Broth - Kasvi) and incubating at $37^{\circ} \mathrm{C}$ for $24 \mathrm{~h}$. The selected colonies were individually added to a steel plate. Then, to this plate, $1 \mu \mathrm{l}$ of formic acid $(70 \%)$ and $1 \mu \mathrm{l}$ of MALDI-TOF MS matrix were added, consisting of a saturated solution of a-cyano-4-hydroxycinnamic acid (Bruker Daltonics, Bremen, Germany), and it was left to air dry. The spectra were obtained using the mass spectrometer MicroFlex LT (Bruker Daltonics) with a nitrogen laser of $60 \mathrm{~Hz}$, in which up to 240 laser photos are triggered in spiral movements to collect 40 steps of shot for each point of tension. In addition, the parameters for detection of mass range were defined to allow the identification from 1960 to $20,137 \mathrm{~m} / \mathrm{z}$, where the source of ions $1 \mathrm{v}$ was $19.99 \mathrm{kv}$, the ion source voltage of $2 \mathrm{kv}$ was 18.24 , and the lens voltage was $6.0 \mathrm{kv}$ for data acquisition (manufacturer's specifications). Previous the identification tests, the equipment was calibrated using a standard bacterial test (E. coli DH5 alpha; Bruker Daltonics). The criteria of the identification score in real-time used were those recommended by the manufacturer: $\geq 2000$ score indicates identification at the species level, score $\geq 1700$ and $<2000$ indicate identification at the level of genus, and $<1700$ score indicates absence of reliable identification. The comparisons between the identifications of the strain by MALDI-TOF MS and other techniques were performed using the R software version 3.0.1 (R Core Team, 2013) with the concordance rates determined by the Kappa coefficient. 


\section{DNA extraction}

The cryopreserved isolates of $S$. aureus were reactivated by sowing in the $\mathrm{BHI}$ medium (Prodimol Biotecnologia) and incubating at $37^{\circ} \mathrm{C}$ for $24 \mathrm{~h}$. Growth bacterial cultures were subjected to DNA extraction, as described by $\mathrm{Gu}$ et al. [40]. The integrity and quantity of extracted DNA were verified by electrophoresis in 1.0\% agarose gel. This material was used in the PCR and RAPD-PCR reactions performed in this study. All primers used in this study were synthesized by Genome Biotechnologies, Brazil.

\section{PCR analysis for the detection of 16S rDNA gene}

The presence of the universal $16 \mathrm{~S}$ bacterial rDNA gene was verified by PCR with the primers DG74 5'AGGAGGTGATCCAACCGCA3' and RW01 5'AACTGGAGGAAGGTGGGGAT3' generating an amplicon of approximately 370 base pairs [9]. The reactions were carried out in a mix containing $2 \times$ Go Taq Green Master Mix ${ }^{\circledR}$ (Promega, Corporation, USA), $\mathrm{MgCl}_{2}(2.5 \mathrm{~mm}), 10 \mu \mathrm{M}$ of each primer, and $50 \mathrm{ng}$ of DNA in a final total reaction volume of $50 \mu \mathrm{l}$. The PCR reaction was performed in a Thermal Cycler Veriti (Applied Biosystems, California, USA). The thermal conditions of PCR amplification were performed according to Xavier et al. [9]. The amplicons were visualized in $1.5 \%$ agarose gel stained with ethidium bromide and photodocumented. As a positive control, a standard strain of $S$. aureus ATCC 43300 was used, and sterile water was used as a negative control.

\section{PCR analysis for the detection of genes $b^{\prime} a_{\mathrm{KPC}}, b^{\prime} a_{\text {OXA23' }}$ blaZ, mecA, and $m^{\prime} c_{A L G A 251}$ related to resistance to the tested beta-lactams}

The presence of the genes bla ${ }_{\mathrm{KPC}}$, bla ${ }_{\mathrm{OXA} 23}$, blaZ, $m e c A m$ and $m e c_{\text {ALGA251 }}$ was verified by PCR. The sequences of the gene targets to be detected and the sizes of the expected fragments amplified by the reaction are indicated in Table-1 [10,14,18,19,21]. The reactions were carried out in a mix containing $2 \times$ Go Taq Green Master $\mathrm{Mix}^{\circledR}$ (Promega, Corporation, USA), $\mathrm{MgCl}_{2}(2.5 \mathrm{~mm})$, $10 \mu \mathrm{M}$ of each primer, and $50 \mathrm{ng}$ of DNA in the final total reaction volume of $50 \mu \mathrm{l}$. The PCR reaction was performed in a Thermal Cycler Veriti (Applied Biosystems, California, USA). The PCR thermal conditions were those described by the authors added in Table-1. The amplicons were visualized in 1.5\% agarose gel stained with ethidium bromide and photodocumented. As a positive control for the detection of the blaZ, mecA, and $m_{\text {mec }}$ ALGA251 a standard strain of $S$. aureus ATCC 43300 was used. For detection of the bla ${ }_{\mathrm{KPC}}$ and $b l a_{\mathrm{OXA} 23}$ genes, DNA of nosocomial isolates of $K$. pneumoniae and $A$. baumannii (genotyped by Ezequiel Dias Foundation from Minas Gerais, Brazil) kindly donated by the microbiology laboratory of State University of Montes Claros were used, respectively. In all the reactions, sterile water was used as a negative control.

\section{RAPD-PCR and statistical analysis}

The genetic profile characterization and identification of the clonal relationship among isolates of $S$. aureus were performed using the RAPD-PCR technique. For the RAPD-PCR reaction, the oligonucleotide S232 was used, and PCR conditions were as described in the literature for the analysis of polymorphism within and among species of $S$. aureus $[7,35]$. The reactions were carried out in a mix containing $1 \times$ Buffer of Taq of Kappa PCR Kit, $\mathrm{MgCl}_{2}$ (2.5 mm), deoxynucleotides $(1 \mu \mathrm{M})$, Taq Polymerase Invitrogen, $(0.5 \mathrm{U}), 1 \mu \mathrm{M}$ of each primer, and $5 \mu \mathrm{l}(50 \mathrm{ng} / \mu \mathrm{l})$ of bacterial DNA in a final total reaction volume of $25 \mu 1$. The amplicons were visualized in $1.8 \%$ agarose gel stained with ethidium bromide and photodocumented. The analysis of the amplification of DNA profiles obtained by RAPD-PCR was performed by visual inspection of two observers and transformed into binary data in an array, according to the presence (1) or (0) absence of bands. To assess the genetic relationship among the isolates, the matrix was subjected to a multivariate "Cluster Analysis" by the method of full thread (complete linkage) for the calculation of the Euclidean distance and generation of a dendrogram in the statistical program Minitab v.16. (Minitab, USA). As a positive control, a standard strain of $S$. aureus ATCC 43300 was used and sterile water was used as a negative control.

\section{Sequencing of PCR products of genes blaZ and} $\boldsymbol{m e c}_{\text {ALGA251 }}$

The PCR products corresponding to the optimization of PCR reactions with the genes blaZ and mec $c_{\text {ALGA251 }}$ were sequenced by the Sanger method (Ludwig Biotech, RS, Brazil - ACTGene Análises Moleculares) using the primers described in Table1. To obtain the amplified sequence by PCR, the sequencing tapes were aligned with the Clustal Omega tool (European Bioinformatics Institute https://www.ebi.ac.uk/Tools/msa/clustalo/), and differences were visualized on an electropherogram (Chromas v.2.6.5 - www.technelysium.com.au) and corrected. After obtaining the amplified sequence, it was used for the BLAST completion (https://blast. ncbi.nlm.nih.gov/Blast.cgi). After the blast, the result obtained was aligned with the sequence resulting from the BLAST using the Clustal Omega tool (European Bioinformatics Institute - https://www.ebi.ac.uk/ Tools/msa/clustalo/).

\section{Results and Discussion}

Phenotypic profile of resistance to beta-lactam antimicrobials

All the isolates proved to be resistant to OXA and CFO (16/16). The resistance index to AMO among isolates was $87.5 \%(14 / 16)$, and ten isolates $(62.5 \%)$ showed resistance to AMP. The resistance to MER was found in $56.25 \%(9 / 16)$ of the isolates (Table-2).

The profile of simultaneous resistance to MER, CFO, OXA, AMP, and AMO was found in 43.75\% of the isolates (7/16). Four isolates (25\%) presented with the resistance profile of CFO, OXA, and AMO. The resistance profiles CFO, OXA, AMO, AMP and 
Table-1: List of primers, sequence, gene target, the amplicon expected size, and references for PCR analysis for the detection of genes related to beta-lactams resistance.

\begin{tabular}{|c|c|c|c|c|}
\hline Primer & Sequence $\left(5^{\prime} \ldots 3^{\prime}\right)$ & Target gene & Amplicon & References \\
\hline $\begin{array}{l}\text { KPC- } 1 a \\
\text { KPC- } 1 b\end{array}$ & $\begin{array}{l}\text { TGTCACTGTATCGCCGTC } \\
\text { CTCAGTGCTCTACAGAAAACC }\end{array}$ & $b / a_{\mathrm{KPC}}$ & $\sim 879 \mathrm{pb}$ & {$[21]$} \\
\hline $\begin{array}{l}\text { OXA 23-F } \\
\text { OXA 23-R }\end{array}$ & $\begin{array}{l}\text { ATGTGTCATAGTATTCGTCG } \\
\text { TCACAACAACTAAAAGCACTG }\end{array}$ & bla $_{\text {OXA23 }}$ & $\sim 1057 \mathrm{pb}$ & [19] \\
\hline $\begin{array}{l}\text { BLAZ-1 } \\
\text { BLAZ-2 }\end{array}$ & $\begin{array}{l}\text { TTAAAGTCTTACCGAAAGCAG } \\
\text { TAAGAGATTGCCTATGCTT }\end{array}$ & $b l a_{z}$ & $\sim 377 \mathrm{pb}$ & [14] \\
\hline $\begin{array}{l}\text { mecAL1 } \\
\text { mecAL2 }\end{array}$ & $\begin{array}{l}\text { TCACCAGGTTCAAC[Y]CAAAA } \\
\text { CCTGAATC[W]GCTAATAATATTTC }\end{array}$ & $m e c_{\mathrm{ALGA251}}$ & $\sim 356 \mathrm{pb}$ & [10] \\
\hline $\begin{array}{l}\text { mecA1 } \\
\text { mecA2 }\end{array}$ & $\begin{array}{l}\text { AGTTCTGCAGTACCGGATTTGC } \\
\text { AAATCGATGGTAAAGGTTGGC }\end{array}$ & mecA & $\sim 533 \mathrm{pb}$ & [18] \\
\hline
\end{tabular}

$\mathrm{PCR}=$ Polymerase Chain Reaction

MER, CFO, and OXA were found in $62.5 \%(10 / 16)$ and $56.25 \%(9 / 16)$ of the isolates. S. aureus resistant to OXA, AMO, AMP, and CFO was isolated from animals with mastitis [7,41-45]. Rossi et al. [44], over a period of 12 months, isolated 116 strains of $S$. aureus from the milk of cows diagnosed with subclinical mastitis on farms in the region of Piracicaba, in the state of São Paulo, Brazil. Among these isolates, there was a low rate of resistance to the antimicrobials OXA (7.8\%) and CFO (4.3\%). However, strains of Staphylococcus spp. isolated from milk of cows with mastitis on farms in Rio Grande do Sul, Brazil, presented with profiles of resistance to AMO $(50 \%)$ and AMP (43.3\%), similar to those found in our study [42]. The high rates of resistance to OXA, AMO, AMP, and $\mathrm{CFO}$, and multidrug resistance identified here reveals the persistence and widespread dissemination of these beta-lactam resistant bacteria in cows with subclinical mastitis in the studied region. Freitas et al. [42] concluded that the multidrug resistance of $S$. aureus to antimicrobials is due to their external use, empirical, or improper use of these drugs for the treatment and/ or prophylaxis of diseases in the bovines' mammary glands.

Carbapenems are beta-lactam antibiotics which are effective against both Gram-negative and Grampositive bacteria [46]. However, carbapenems are not the first choice drug in clinical mastitis treatment [46]. Gram-negative microorganisms, such as E. coli, $K$. pneumoniae, and A. baumannii, are described in the literature as pathogens involved in the mastitis etiology [23-26]. The possibility of antimicrobial resistance genes transferring between the same species and different species in a milking environment sheltering cows with subclinical mastitis led us to investigate the susceptibility of $S$. aureus isolates to MER. The results of the disk diffusion test revealed that more than 50\% of the $S$. aureus tested showed phenotypic resistance to MER (Table-2). The resistance mechanisms of Gram-negative germs to carbapenem antibiotics are known [47]; however, there are reports of this resistance being present in Gram-positive bacteria, among which is $S$. aureus. To the best of our knowledge, this is the first time in literature that the phenotypic resistance to carbapenems has been reported in strains of
S. aureus isolated from the milk of bovines diagnosed with subclinical mastitis.

\section{Identification of $S$. aureus and genotypic analysis of resistance to beta-lactam antimicrobials}

The evaluation of the quality of the DNA extracted and the confirmation of the bacterial isolates were performed by PCR of the universal $16 \mathrm{~S}$ rDNA region. All the isolates amplified a fragment of approximately $370 \mathrm{bp}$ corresponding to the $16 \mathrm{~S}$ rDNA bacterial universal gene. The confirmation of the species $S$. aureus at a genomic level was previously asserted by the presence of the femA gene marker in the samples, according to Xavier et al. [9]. All isolates and standard strains tested positive for the gene femA. In addition to the gene $f e m \mathrm{~A}$, the nuc gene and $16 \mathrm{~S}$ rDNA gene have also been reported as species-specific markers for $S$. aureus and are recognized as robust tests for the identification of the species of this microorganism $[5,41,48]$.

The MALDI-TOF MS analysis of isolates confirmed the results of the genomic analysis, where all the isolates exhibited a proteomic profile of $S$. aureus (Table-2). This method has been successfully used for the identification of $S$. aureus isolated from samples of bovine milk $[5,48]$.

The PCR standardization for the detection of resistance to antimicrobials was performed in standard strains and nosocomial isolates containing the genes studied here. Figure-1 shows the result of the optimization of the genes $b l a_{K P C}, b l a_{O X A 23}$, blaZ, mecA, and $m e c_{A L G A 251}$ related to beta-lactam resistance.

The PCR sequencing results of $S$. aureus ATCC 43300 standard strain corresponding to the gene blaZ revealed that it presented $100 \%$ similarity to a partial sequence of the gene blaZ of $S$. aureus stored in GenBank (access number: DQ16050). The PCR product of the strain pattern of $S$. aureus corresponding to $m e c A$ and $m e c_{\text {ALGA251 }}$ genes was also sequenced and showed similarity of $91 \%$ and $96 \%$ to a partial sequence of the gene mecA that encodes for a PBP2A of strain of Methicillin-resistant S. aureus (MRSA) stored in GenBank access numbers MH798869.1 and MH798864.1, respectively. The results of the sequencing of PCR products corresponding to the genes mecA, 


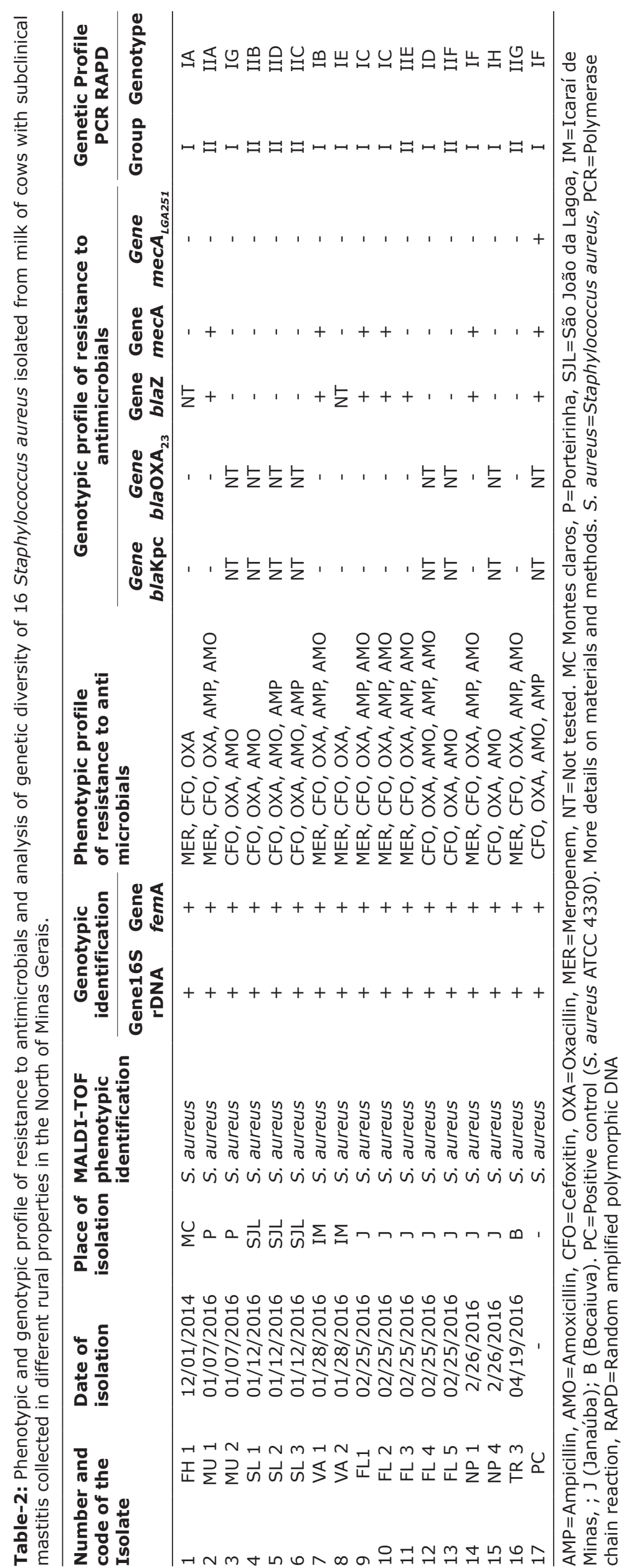


mec $_{\mathrm{ALGA251}}$, and blaZ analyzed here have confirmed that these genes have approximate sizes of amplified fragments to those cited by the authors of these primers (Table-1 and Figure-1). After the standardization of PCR with standard strains, the S. aureus isolates were submitted to specific PCR for the screening of the genes $b l a_{\mathrm{KPC}}, b l a_{\mathrm{OXA} 23}, b l a \mathrm{Z}, m e c \mathrm{~A}$, and $m e c_{\mathrm{ALGA} 251}$ related to beta-lactam resistance. All the isolates that showed phenotypic resistance to the antimicrobial MER were subjected to PCR for the screening of the genes $b l a_{K P C}$ bla $a_{O X 23}$ related to resistance to carbapenems. None of the nine tested isolates amplified the genes $b l a_{\mathrm{KPC}}$ and/or $b l a_{\mathrm{OXA} 23}$ in the PCR reactions (Table-2). Until the present moment, no report of $S$. aureus carrying the $b l a_{\mathrm{KPC}}$ and/or $b l a_{\mathrm{OXA} 23}$ genes has been described in the literature corroborating with the results obtained here. However, the screening of other genes related to the presence of resistance to carbapenems in these samples, among which are those described by Codjoe and Donkor [47], could be a strategy to be used to elucidate the in vitro resistance of these isolates to MER.

Isolates resistant to AMO and AMP were subjected to a PCR screening for the gene blaZ. The presence of an amplicon corresponding to a region of the blaZ gene was detected in $41.8 \%$ isolates (6/14) and in the tested standard strain of $S$. aureus ATCC 43300 (Table-2). Although the phenotypic resistance to AMP has been found in 14 isolates, only six tested positive for the presence of the gene blaZ The same isolates

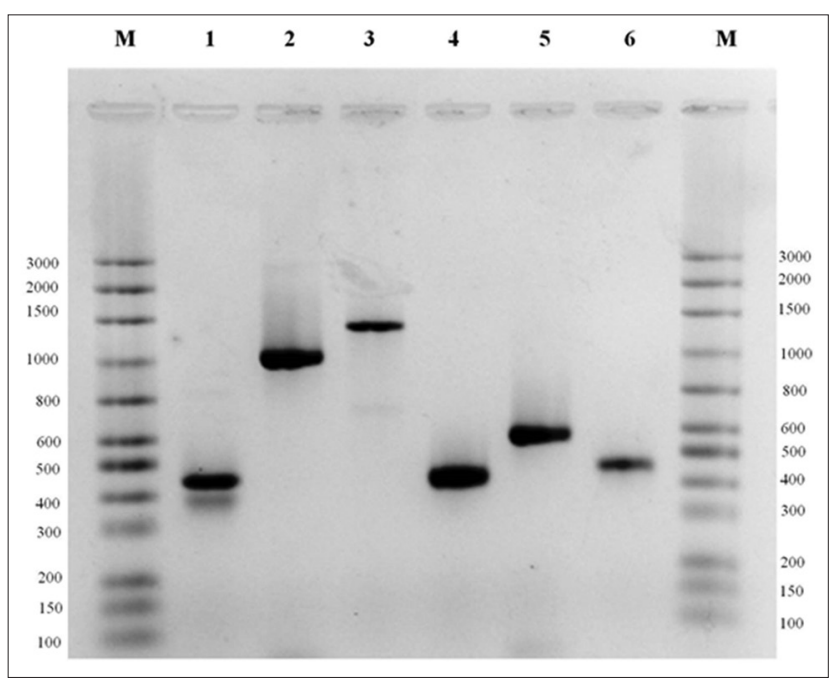

Figure-1: Polymerase chain reaction (PCR) optimization with positive controls for universal bacteria 165 rDNA, bla $_{O X A 23,}$ bla $a_{K P C}$ bla $z_{Z^{\prime}}$ mecA, and $\operatorname{mec}_{\mathrm{ALG} 250}$ genes M: Molecular weight' marker Mid-Range (Cellco Biotecnologia), Line 1: PCR Staphylococcus aureus strain ATCC 43300 for detection of universal bacteria $16 \mathrm{~S}$ rDNA gene ( 370pb). Line 2: PCR nosocomial Klebsiella pneumoniae isolate for detection of bla $_{K P C}$ gene ( $\left.876 \mathrm{pb}\right)$. Line 3: PCR Acinetobacter baumannii isolate for detection of bla $a_{\text {XXA23 }}$ gene $(\sim 1057 \mathrm{pb})$ Line 4 : PCR S. aureus strain ATCC 43300 for detection of bla gene $(\sim 377 \mathrm{pb})$. Line 5: PCR S. aureus strain ATCC 43300 for detection of mecA gene (533pb). Line 6: PCR S. aureus strain ATCC 43300 for detection of gene mec $_{\text {ALGA251 }}$ ( $\sim 356 \mathrm{pb})$. Electrophoresis on $1.5 \%$ agarose gel. that tested positive for the gene blaZ presented simultaneous resistance phenotypic profiles to AMO (6/10) (Table-2). Strains of $S$. aureus isolated from bovines with mastitis were already described in literature as bearers of the genes blaZ, blaI, and blaR [14,17,48]. Qu et al. [34] detected the presence of the gene blaZ in $95 \%$ of the $S$. aureus strains isolated from the milk of cows with mastitis in different regions of China.

The resistance of $S$. aureus to penicillin and its analogs is explained by the production of the enzyme $\beta$-lactamase, encoded by a regulatory cluster composed of the genes blaZ, blaI, and blaR [17]. The results of phenotypic resistance to AMO and AMP whose blaZ gene was not detected may be explained by the emergence of a mutation in this gene in $S$. aureus samples tested here. The search for the gene regions blaI and blaR in these samples could determine the genetic origin of resistance to these beta-lactams.

Isolates resistant to OXA and CFO were subjected to PCR for the screening of genes mecA and its counterpart $m e c_{\mathrm{ALGA} 251}$. Although the phenotypic resistance to OXA and CFO has been found in $100 \%$ of the isolates $(16 / 16)$, only $31.25 \%(5 / 16)$ tested positive for the presence of gene mecA related to methicillin/OXA/CFO resistance. None of the isolates tested positive for the $m e c_{\text {ALGA251 }}$ gene which is homologous to the gene mecA. Dias et al. [18] also obtained divergence between the phenotypic and genotypic results associated with $S$. aureus resistance to OXA. Although 55.5\% of S. aureus isolates have proved to be phenotypically resistant to OXA, only $11 \%$ carried the mecA gene. The authors justify the genotypic resistance to methicillin/OXA found in $S$. aureus isolates to the presence of homologous genes to mecA, among which is mecC Rossi et al. [44] reported the presence of gene mecA in four of the nine $S$. aureus phenotypically resistant to OXA isolated from milk of a herd with subclinical mastitis. None of these isolates tested positive for the gene $m e c \mathrm{C}$. The $m e c \mathrm{C}$ gene, also known as gene $m e c_{\text {ALGA251, was }}$ identified in $S$. aureus isolates from both humans and animals $[10,12,44,49]$. This gene has $70 \%$ of homology to the mecA gene [10]. According to Rolo et al. [12], the $\beta$-lactams resistance mediated by $m e c A$ can be explained through four distinct mechanisms: Accumulation of substitutions in a specific domain of $\beta$-lactamase; diversification of the gene promoter; and acquisition of a new cassette Staphylococcal Cassette Chromosome mec and adaptation to genetic background.

\section{Analysis of the genetic diversity of $\boldsymbol{S}$. aureus}

In this study, the analysis of genetic diversity of 16 isolates resistant to beta-lactams using the RAPD technique produced 19 different fragments (490 bp, $500 \mathrm{bp}, 510 \mathrm{bp}, 600 \mathrm{bp}, 610 \mathrm{bp}, 700 \mathrm{bp}, 750 \mathrm{bp}$, 790 bp, 800 bp, 810 bp, 900 bp, 1000 bp, 1100 bp, $1400 \mathrm{bp}, 1500 \mathrm{bp}, 1900 \mathrm{bp}, 2000$ bp, $2500 \mathrm{bp}$, and $3000 \mathrm{bp}$ ). For the bands sharing analysis, the bands in a range between 450 and 3000 base pairs were considered (Figure-2A). 


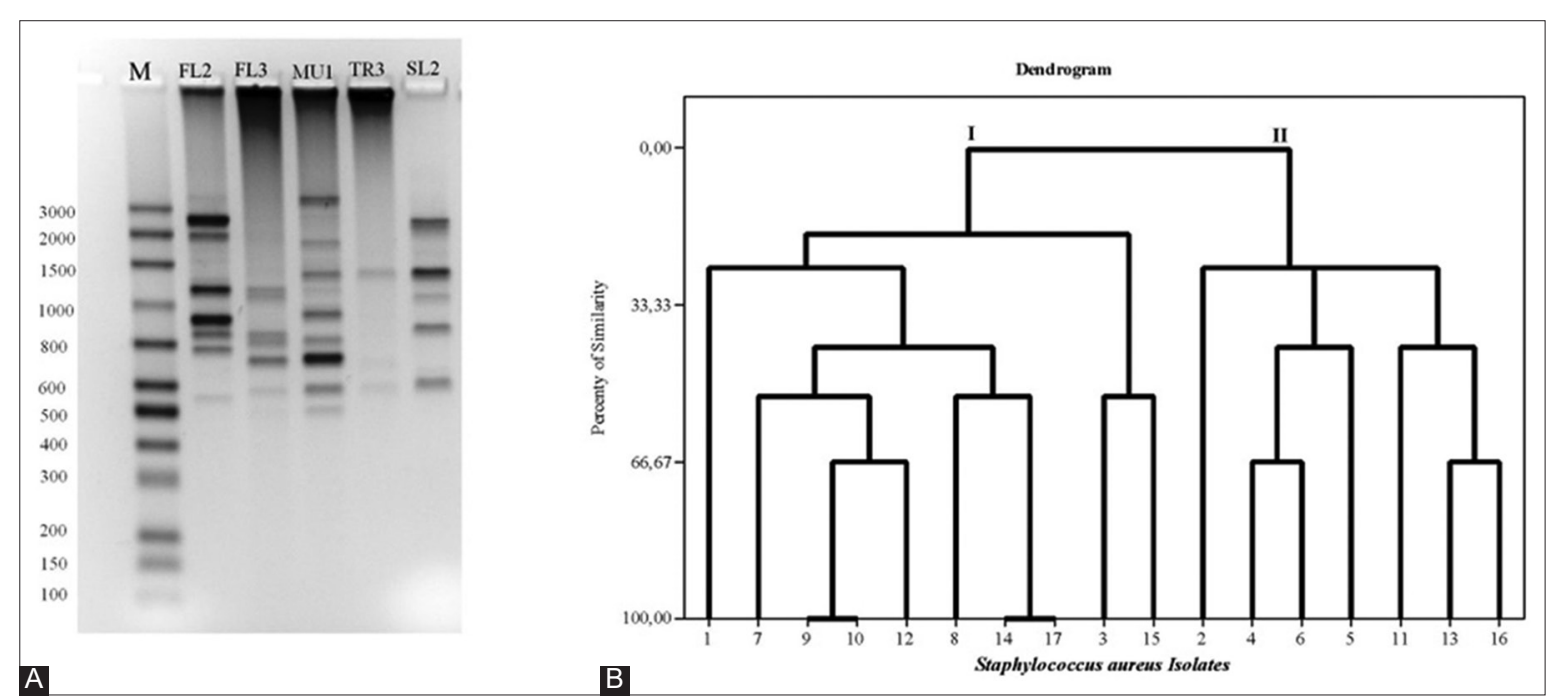

Figure-2: Random amplified polymorphic DNA (RAPD)-polymerase chain reaction (PCR) and dendrogram of genetic relationship of the Staphylococcus isolated from milk of bovines diagnosed with subclinical mastitis. Panel A: Electrophoresis on $1.8 \%$ agarose gel containing RAPD-PCR amplicons of five isolates of Staphylococcus aureus. M: Molecular weight marker Mid-Range (Cellco Biotecnologia), Line 1 to 5: RAPD-PCR of S. aureus FL2, FL3, MU1, TR3, and SL2 isolates. Panel B: Dendrogram of genetic relationship of the Staphylococcus aureus $(n=16)$ isolated from milk of bovines diagnosed with subclinical mastitis. Dendrogram of genetic relationship of the Staphylococcus aureus $(n=16)$ isolated from milk of bovines diagnosed with subclinical mastitis. The 16 isolates were divided into two groups (I and II) according to the degree of similarity based on the Euclidean distance calculation. The RAPD-PCR profile of standard strain of S. aureus ATCC 43300 was used for the dendrogram generation (corresponding to 17).

The binary matrix made by visual observation of the presence or absence of these bands after being subjected to cluster analysis for the Euclidean distance calculation generated a dendrogram of genetic relationships among isolates of $S$. aureus (Figure-2B). These were grouped into two different groups of which $56.25 \%(9 / 16)$ showed a profile of Group I and $43.75 \%(7 / 16)$ of Group II. Still, according to the Euclidean distance calculation, it was possible to determine 15 different genotypes (IA to IH and IIA to IIG), which revealed heterogeneity of genotypes of $S$. aureus not only among isolates from different rural properties but also in those isolated within the same herd (Figures-2A and B, Table-2). The genetic diversity of $S$. aureus obtained from cows' milk from others had similar results to this work on analyzing through the PCR-RAPD technique $[7,36,38]$. However, clonality was verified (100\% of similarity) between the isolates 9 (FL1) and 10 (FL2) obtained from the same rural property in the municipality of Janaúba. The comparison of the genetic relationships among these isolates showed convergence between the phenotypic profiles of sensitivity to antibiotics (MER, CFO, OXA, AMP, and AMO) and the characterization of the genetic profile by polymorphism analysis based on PCR-RAPD-(IC) (Table-2). A degree of similarity $(100 \%)$ was also found between the isolate 14 (NP1) and the standard strain of $S$. aureus ATCC 43300 used for validation of the PCR-RAPD method. Even though both of them presented the same phenotypic antibiotic resistance profile, the only difference presented between $S$. aureus ATCC 43300 and isolate 14 was related to detection of amplicon to the gene $m e c_{\text {ALGA251 }}$ (Table-2).
Epidemiological studies have contributed to the clarification of the sources and routes of pathogen transmission related to mastitis [7,34]. Pathogenic strains can be transferred from one animal to another by different sources, including by the animal itself. The transmission path includes contact between animals, beds of creation, milking equipment, and the milkers' hands $[7,33]$.

\section{Conclusion}

It is possible to conclude from this work that strains of $S$. aureus isolated from the milk of herds diagnosed with subclinical mastitis showed phenotypic resistance to the tested beta-lactams. In addition, strains carrying genes related to beta-lactam resistance, among which blaZ and mecA, were reported. Hence, the $S$. aureus (MRSA) found here deserves special attention, once the milk in the region surveyed is marketed and used for human consumption in natura or even for the production of artisan cheese. The presence of MER resistant strains may indicate the misuse of antimicrobials in herds in the studied region. The PCR-RAPD analysis showed a heterogeneous profile among isolates in different rural properties. Studies with a greater number of $S$. aureus samples collected from the milk of cows diagnosed with subclinical mastitis during longer periods will be necessary for the better elucidation of the molecular epidemiology in the studied region. In particular, the elucidation of the mechanisms of gene transfer conferring resistance to antimicrobial agents in herds, especially those treated but remain with subclinical mastitis that is not diagnosed, since they are a potential reservoir of microorganisms that cause infection. The gene flow mapping 
of antimicrobial resistance and genes related to toxin production in milking environments can provide useful information for the management of clinical and subclinical mastitis in animal production.

\section{Authors' Contributions}

GAADS, ACA, MASX, DAS and AREOX designed the study. LMVD and CNS collected the samples. GAADS, CNS, and ACA performed the experiments. GAADS, ACA, and AREOX performed data analysis. AREOX and GAADS wrote the manuscript. All authors edited, read, and approved the final manuscript.

\section{Acknowledgments}

The authors would like to thank the National Council for Scientific and Technological Development (CNPq, Portuguese: Conselho Nacional de Desenvolvimento Científico e Tecnológico), Foundation for Supporting Research in the State of Minas Gerais (Fapemig) (\#APQ-01786-13), and the Dean's Office for Research studies of UFMG for funding this research.

\section{Competing Interests}

The authors declare that they have no competing interests.

\section{Publisher's Note}

Veterinary World remains neutral with regard to jurisdictional claims in the published institutional affiliation.

\section{References}

1. Ismail, Z.B. (2017) Mastitis vaccines in dairy cows: Recent developments and recommendations of application. Vet. World, 10(9): 1057-1062.

2. Monistero, V., Graber, H.U., Pollera, C., Cremonesi, P., Castiglioni, B., Bottini, E., Ceballos-Marquez, A., Lasso-Rojas, L., Kroemker, V., Wente, N., Petzer, I.M., Santisteban, C., Runyan, J., dos Santos, M.V., Alves, B.G., Piccinini, R., Bronzo, V., Abbassi, M.S., Said, M.B. and Moroni, P. (2018) Staphylococcus aureus isolates from bovine mastitis in eight countries: Genotypes, detection of genes encoding different toxins and other virulence genes. Toxins, 10(6): 2-22.

3. Kadlec, K., Entorf, M. and Peters, T. (2019) Occurrence and characteristics of livestock-associated methicillin-resistant Staphylococcus aureus in quarter milk samples from dairy cows in Germany. Front. Microbiol., 10: 1-6.

4. Pumipuntu, N., Tunyong, W., Chantratita, N., Diraphat, P., Pumirat, P., Sookrung, N., Chaicumpa, W. and Indrawattana, N. (2019) Staphylococcus spp. associated with subclinical bovine mastitis in central and Northeast provinces of Thailand. PeerJ, 7: e6587.

5. Wald, R., Hess, C., Urbantke, V., Wittek, T. and Baumgartner, M. (2019) Characterization of Staphylococcus species isolated from bovine quarter milk samples. Animals, 90(5): 1-16.

6. Busanello, M., Rossi, R.S., Cassoli, L.D., Pantoja, J.C.F. and Machado, P.F. (2017) Estimation of prevalence and incidence of subclinical mastitis in a large population of Brazilian dairy herds. J. Dairy Sci., 100(8): 6545-6553.

7. Xavier, A.R.E.O., Almeida, A.C., Souza, C.N., Silva, L.M.V., Ruas, A.X.A., Sanglard, D.A., Júnior, A.F.M., Oliveira, A.M.E. and Xavier, M.A.S. (2017) Phenotypic and genotypic characterization of Staphylococcus aureus isolates in milk from flocks diagnosed with subclinical mastitis. Genet. Mol. Res., 16(12): 1-11.

8. Ganda, E.K., Bisinotto, R.S., Decter, D.H. and Bicalho, R.C. (2016) Evaluation of an on-farm culture system (Accumast) for fast identification of milk pathogens associated with clinical mastitis in dairy cows. PLoS One, 11(5): 1-16.

9. Xavier, A.R.E.O., Lima, E.R., Oliveira, A.M.E., Cardoso, L., Santos, J., Cangussu, C.H.C., Leite, L.N., Quirino, M.C.L., Júnior, I.G.C., Oliveira, D.A. and Xavier, M.A.S. (2017) Genetic diversity of Bacillus spp. producers of amylase isolated from the soil. Genet. Mol. Res., 16(3): 1-10.

10. García-Álvarez, L., Holden, M.T.G., Lindsay, H., Webb, C.R., Brown, D.F.J., Curran, M.D., Walpole, E., Brooks, K., Pickard, D.J., Teale, C., Parkhill, J., Bentley, S.D., Edwards, G.F., Girvan, E.K., Kearns, A.M., Pichon, B., Hill, R.L.R., Larsen, A.R., Skov, R.L., Peacock, S.J., Maskell, D.J. and Holmes, M.A. (2011) Meticillin-resistant Staphylococcus aureus with a novel $m e c \mathrm{~A}$ homologue in human and bovine populations in the UK and Denmark: A descriptive study. Lancet Infect. Dis., 11(8): 595-603.

11. Argudín, M., Deplano, A., Meghraoui, A., Dodémont, M., Heinrichs, A., Denis, O., Nonhoff, C. and Roisin, S. (2017) Bacteria from animals as a pool of antimicrobial resistance genes. Antibiotics, 6(2): 1-38.

12. Rolo, J., Worning, P., Nielsen, J.B., Sobral, R., Bowden, R., Bouchami, O., Damborg, P., Guardabassi, L., Perreten, V., Westh, H., Tomasz, A., de Lencastre, H. and Miragaia, M. (2017) Evidence for the evolutionary steps leading to mecA-mediated $\beta$-lactam resistance in staphylococci. PLoS Genet., 13(4): 1-22.

13. Michael, G.B., Feßler, A.T., Eidam, C., Wendlandt, S., Lopes, G.V., Freitag, C., Kadlec, K. and Schwarz, S. (2015) Emerging issues in antimicrobial resistance of bacteria from food-producing animals. Future Microbiol., 10(3): 427-443.

14. Olsen, J.E., Christensen, H. and Aarestrup, F.M. (2006) Diversity and evolution of blaZ from Staphylococcus aureus and coagulase-negative staphylococci. J. Antimicrob. Chemother, 57(3): 450-460.

15. Bagcigil, A.F., Taponen, S., Koort, J., Bengtsson, B., Myllyniemi, A. and Pyörälä, S. (2012) Genetic basis of penicillin resistance of $S$. aureus isolated in bovine mastitis. Acta Vet. Scand., 54: 1-7.

16. Mendonça, E.C.L., Marques, V.F., Melo, D.A., Alencar, T.A., Coelho, I.S., Coelho, S.M.O. and Souza, M.M.S. (2012) Caracterização fenogenotípica da resistência antimicrobiana em Staphylococcus spp. isolados de mastite bovina. Pesqui. Vet. Bras., 32(9): 859-864.

17. Tasara, T., Cernela, N. and Stephan, R. (2013) Function impairing mutations in blaZ and blaR genes of penicillin-susceptible Staphylococcus aureus strains isolated from bovine mastitis. Schweiz. Arch. Tierheilkd., 155(6): 359-363.

18. Dias, N.L., Silva, D.C.B., Oliveira, D.C.B., Fonseca, J.A., Sales, M.L. and Silva, N. (2011) Detecção dos genes de Staphylococcus aureus, enterotoxinas e de resistência à meticilina em leite. Arq. Bras. Med. Vet. Zootec., 63(6): 1547-1552.

19. Fonseca, E.L., Scheidegger, E., Freitas, F.S., Cipriano, R. and Vicente, A.C.P. (2013) Carbapenem-resistant Acinetobacter baumannii from Brazil: Role of carO alleles expression and $\mathrm{bl}_{\text {аоха } 2} 3$ gene. BMC Microbiol., 13: 1-7.

20. Carvalho, A.A., Cardoso, L.L., Nogueira, H.S., Menezes, E.V., Xavier, M.A.S., Barreto, N.A.P., Fernandes, L.F. and Xavier, A.R.E.O. (2016) Characterization and molecular epidemiology of extensively prevalent nosocomial isolates of drug-resistant Acinetobacter spp. Genet. Mol. Res., 15(3): 1-11.

21. Yigit, H., Queenan, A.M., Anderson, G.J., DomenechSanchez, A., Biddle, J.W., Steward, C.D., Alberti, S., Bush, K. and Tenover, F.C. (2001) Novel carbapenem-hydrolyzing 
beta-lactamase, KPC-1, from a carbapenem-resistant strain of Klebsiella pneumoniae. Antimicrob. Agents Chemother., 45(4): 1151-1161.

22. Lima, E.R., Carvalho, A.A., Xavier, M.A.S., Curzio, H.S.N., Guedes, H.R., Fernandes, L.F., Almeida, A.C., Menezes, E.V., Barreto, N.A.P., Cardoso, L.L.S. and Xavier, A.R.E.O. (2019) Characterization and molecular epidemiology of extensively prevalent nosocomial isolates of drug-resistant Klebsiella pneumoniae. Genet. Mol. Res., 18(1): 1-11.

23. Müller, S., Janßen, T. and Wieler, L.H. (2014) Multiresistente Acinetobacter baumannii in in veterinary medicine emergence of an underestimated pathogen? Berl. Munch. Tierarztl. Wochenschr., 127(11-12): 435-446.

24. Nam, H.M., Lim, S.K., Kang, H.M., Kim, J.M., Moon, J.S., Jang, K.C., Kim, J.M., Joo, Y.S. and Jung, S.C. (2020) Prevalence and antimicrobial susceptibility of Gramnegative bacteria isolated from bovine mastitis between 2003 and 2008 in Korea. J. Dairy Sci., 92(5): 2020-2026.

25. Nonnemann, B., Lyhs, U., Svennesen, L., Kristensen, K.A., Klaas, I.C. and Pedersen, K. (2019) Bovine mastitis bacteria resolved by MALDI-TOF mass spectrometry. J. Dairy Sci., 102(3): 2515-2524.

26. Bonsaglia, E.C.R., Gomes, M.S., Canisso, I.F., Zhou, Z., Lima, S.F., Rall, V.L.M., Oikonomou, G., Bicalho, R.C. and Lima, F.S. (2017) Milk microbiome and bacterial load following dry cow therapy without antibiotics in dairy cows with healthy mammary gland. Sci. Rep., 7: 1-10.

27. Mulani, M.S., Kamble, E.E., Kumkar, S.N., Tawre, M.S. and Pardesi, K.R. (2019) Emerging strategies to combat ESKAPE pathogens in the era of antimicrobial resistance: A review. Front. Microbiol., 10: 1-24.

28. La, M.V., Jureen, R., Lin, R.T.P. and Teob, J.W.P. (2014) Unusual detection of an acinetobacter class D carbapenemase gene, $b a_{\mathrm{OXA}-23}$, in a clinical Escherichia coli isolate. J. Clin. Microbiol., 52(10): 3822-3823.

29. Zhao, Y., Hu, K., Zhang, J., Guo, Y., Fan, X., Wang, Y., Mensah, S.D., Zhang, X., Mensal, S.D. and Zhang, X. (2019) Outbreak of carbapenem-resistant Acinetobacter baumannii carrying the carbapenemase OXA-23 in ICU of the eastern Heilongjiang province, China. BMC Infect. Dis., 19(1): 1-7.

30. Chavda, K.D., Chen, L., Jacobs, M.R., Bonomo, R.A. and Kreiswirth, B.N. (2016) Molecular diversity and plasmid analysis of KPC-producing Escherichia coli. Antimicrob. Agents Chemother., 60(7): 4073-4081.

31. Hazen, T.H., Mettus, R., McElheny, C.L., Bowler, S.L., Nagaraj, S., Doi, Y. and Rasko, D.A. (2018) Diversity among bla ${ }_{\mathrm{KPC}}$-containing plasmids in Escherichia coli and other bacterial species isolated from the same patients. Sci. Rep., 8(1): 1-11.

32. Xavier, M.A.S., De Luca, M., Carvalho, A.A., Cardoso, L.F. and Xavier, A.R.E.O. (2019) Molecular detection on the $b_{l} a_{\mathrm{KPC}}$ gene in the extensively prevalent nosocomial isolates of drug resistant Acinetobacter spp at hospital in southeastern region of Brazil. Braz. J. Heal. Pharm., 1: 21-25.

33. Mcmillan, K., Moore, S.C., Mcauley, C.M., Fegan, N. and Fox, E.M. (2016) Characterization of Staphylococcus aureus isolates from raw milk sources in Victoria, Australia. BMC Microbiol., 16(1): 1-12.

34. Qu, Y., Zhao, H., Nobrega, D.B., Cobo, E.R., Han, B., Zhao, Z., Li, S., Li, M., Barkema, H.W. and Gao, J. (2019) Molecular epidemiology and distribution of antimicrobial resistance genes of Staphylococcus species isolated from Chinese dairy cows with clinical mastitis. J. Dairy Sci., 102(2): 1571-1583.

35. Idil, N. and Bilkay, I.S. (2014) Application of RAPDPCR for determining the clonality of methicillin-resistant
Staphylococcus aureus isolated from different hospitals. Braz. Arch. Biol. Technol., 57(5): 548-553.

36. Wang, D., Zhang, L., Yong, C., Shen, M., Ali, T., Shahid, M., Han, K., Zhou, X. and Han, B. (2017) Relationships among superantigen toxin gene profiles, genotypes, and pathogenic characteristics of Staphylococcus aureus isolates from bovine mastitis. J. Dairy Sci., 100(6): 4276-4286.

37. Szaluś-Jordanow, O., Krysztopa-Grzybowska, K., Czopowicz, M., Moroz, A., Mickiewicz, M., Lutyńska, A., Kaba, J., Nalbert, T. and Frymus, T. (2018) MLST and RAPD molecular analysis of Staphylococcus aureus subsp. anaerobius isolated from goats in Poland. Arch. Microbiol., 200(9): 1407-1410.

38. Akindolire, M.A., Kumar, A. and Ateba, C.N. (2018) Genetic characterization of antibiotic-resistant Staphylococcus aureus from milk in the North-West Province, South Africa. Saudi J. Biol. Sci., 25(7): 1348-1355.

39. CLSI. (2017) Performance Standards for Antimicrobial Susceptibility Testing. CLSI Supplement M100. 27 $7^{\text {th }}$ ed. Clinical and Laboratory Standards Institute, Wayne, PA.

40. Gu, J., Li, H., Li, M., Vuong, C., Otto, M., Wen, Y. and Gao, Q. (2005) Bacterial insertion sequence IS256 as a potential molecular marker to discriminate invasive strains from commensal strains of Staphylococcus epidermidis. $J$. Hosp. Infect., 61(4): 342-348.

41. Hamid, S., Bhat, M.A., Mir, I.A., Taku, A., Badroo, G.A., Nazki, S. and Malik, A. (2017) Phenotypic and genotypic characterization of methicillin-resistant Staphylococcus aureus from bovine mastitis. Vet. World, 10(3): 363-367.

42. Freitas, C.H., Mendes, J.F., Villarreal, P.V, Santos, P.R., Gonçalves, C.L., Gonzales, H.L. and Nascente, P.S. (2018) Identification and antimicrobial susceptibility profile of bacteria causing bovine mastitis from dairy farms in Pelotas, Rio Grande do Sul. Braz. J. Biol., 78(4): 661-666.

43. Käppeli, N., Morach, M., Corti, S., Eicher, C., Stephan, R. and Johler, S. (2018) Staphylococcus aureus related to bovine mastitis in Switzerland: Clonal diversity, virulence gene profiles, and antimicrobial resistance of isolates collected throughout 2017. J. Dairy Sci., 102(4): 3274-3281.

44. Rossi, B.F., Bonsaglia, E.C.R., Castilho, I.G., Dantas, S.T.A., Salina, A., Langoni, H., Pantoja, J.C.F., Budri, P.E., Fitzgerald-Hughes, D., Júnior, A.F. and Rall, V.L.M. (2019) Genotyping of long term persistent Staphylococcus aureus in bovine subclinical mastitis. Microb. Pathog., 132: 45-50.

45. Shah, M.S., Qureshi, S., Kashoo, Z., Farooq, S., Wani, S.A., Hussain, M.I., Banday, M.S., Khan, A.A., Gull, B., Habib, A., Khan, S.M. and Dar, B.A. (2019) Methicillin resistance genes and in vitro biofilm formation among Staphylococcus aureus isolates from bovine mastitis in India. Comp. Immunol. Microbiol. Infect. Dis., 64: 117-124.

46. Krömker, V. and Leimbach, S. (2017) Mastitis treatment reduction in antibiotic usage in dairy cows. Reprod. Dom. Anim., 52(3): 21-29.

47. Codjoe, F. and Donkor, E. (2017) Carbapenem resistance: A review. Med. Sci., 6(1): 1-28.

48. Zaatout, N., Ayachi, A., Kecha, M. and Kadlec, K. (2019) Identification of staphylococci causing mastitis in dairy cattle from Algeria and characterization of Staphylococcus aureus. J. Appl. Microbiol., 127(5): 1305-1314.

49. Harrison, E.M., Paterson, G.K., Holden, M.T.G., Morgan, F.J.E., Larsen, A.R., Petersen, A., Leroy, S., De Vliegher, S., Perreten, V., Fox, L.K., Lam, T.J.G., Sampimon, O.C., Zadoks, R.N., Peacock, S.J., Parkhill, J. and Holmes, M.A. (2013) A Staphylococcus xylosus isolate with a new mecC allotype. Antimicrob. Agents Chemother., 57(3): 1524-1528. 